\title{
Comparison of five parasitological techniques for laboratory diagnosis of Balantidium coli cysts
}

Comparação de cinco técnicas parasitológicas para diagnóstico laboratorial de cistos de Balantidium coli

Alynne da Silva Barbosa ${ }^{1 *}$; Otilio Machado Pereira Bastos²; Claudia Maria Antunes Uchôa²; Alcides Pissinatti;

Augusto César Machado Pereira Bastos²; Igo Vieira de Souza'; Laís Verdan Dib룰 Eduarda Peixoto Azevedo²;

Mayara Perlingeiro de Siqueira²; Matheus Lessa Cardozo ${ }^{2}$; Maria Regina Reis Amendoeira ${ }^{1}$

\author{
${ }^{1}$ Laboratório de Toxoplasmose, Instituto Oswaldo Cruz, Fundação Oswaldo Cruz - Fiocruz-RJ, Rio de Janeiro, RJ, Brasil \\ ${ }^{2}$ Departamento de Microbiologia e Parasitologia, Instituto Biomédico, Universidade Federal Fluminense - UFF, Niterói, RJ, Brasil \\ ${ }^{3}$ Centro de Primatologia do Rio de Janeiro - CPRJ, Instituto Estadual do Ambiente, Rio de Janeiro, RJ, Brasil \\ ${ }^{4}$ Serviço de Criação de Primatas não humanos - CECAL, Fundação Oswaldo Cruz - Fiocruz-RJ, Rio de Janeiro, RJ, Brasil
}

Received December 10, 2015

Accepted May 25, 2016

\begin{abstract}
Balantidium coli is a protozoon that can cause dysentery in humans, pigs and nonhuman primates, with zoonotic potential. In the literature, there is still little information on the effectiveness of different laboratory techniques for diagnosing this disease. This study compared and evaluated the performance of the Lutz, modified Ritchie, Faust, modified Sheather and direct examination techniques for detecting cysts of this protozoon. Between 2012 and 2014, 1905 fecal samples were collected from captive animals in the state of Rio de Janeiro. Of these, 790 were obtained from the rectum of pigs and 1115 from enclosures occupied by nonhuman primates. B. coli cysts were most evident through direct examination (22.4\% of the samples) and the Lutz technique $(21 \%)$. Fair agreement (Kappa $=0.41 ; \mathrm{p}<0.05)$ was observed only between direct examination and Lutz. The flotation techniques (Faust and modified Sheather) did not show good recovery of cysts. A statistically significant difference $(\mathrm{p}<0.05)$ in the frequency of cysts between pigs and nonhuman primates could only be observed through direct examination and the Lutz technique. The most efficient method for diagnosing this parasitosis was seen to an association between direct examination and the spontaneous sedimentation technique.
\end{abstract}

Keywords: Balantidium coli, parasitological techniques, cysts, laboratory diagnosis.

\section{Resumo}

Balantidium coli é um protozoário que pode determinar disenteria em humanos, suínos e primatas não humanos apresentando potencial zoonótico. Na literatura ainda são escassas as informaçóes sobre a eficiência das diferentes técnicas laboratoriais para o diagnóstico dessa parasitose. Este estudo comparou e avaliou o desempenho das técnicas de Lutz, Ritchie modificada, Faust, Sheather modificada e do exame direto para a detecção de cistos desse protozoário. Entre 2012 e 2014, foram coletadas 1905 amostras fecais de animais cativos no Estado do Rio de Janeiro. Dessas, 790 foram obtidas da ampola retal de suínos e 1115 dos recintos de primatas não humanos. Cistos de $B$. coli foram 22,4\% mais evidenciados pelo exame direto; e pela técnica de Lutz, $21 \%$ das amostras. Concordância regular (Kappa = 0,41; $\mathrm{p}<$ 0,05 ) foi observada somente entre exame direto e Lutz. As técnicas de flutuação, Faust et al. e Sheather modificada não apresentaram boa recuperação dos cistos. Diferença estatística significativa $(\mathrm{p}<0,05)$ na frequência de cistos entre suínos e primatas não humanos pode ser observada somente no exame direto e na técnica de Lutz. A metodologia mais eficiente para diagnóstico dessa parasitose foi observada pela associação do exame direto e da técnica de sedimentação espontânea.

Palavras-chave: Balantidium coli, técnicas parasitológicas, cistos, diagnóstico laboratorial.

*Corresponding author: Alynne da Silva Barbosa. Laboratório de

Toxoplasmose, Instituto Oswaldo Cruz, Fundação Oswaldo Cruz - Fiocruz-RJ,

Avenida Brasil, 4365, Manguinhos, CEP 21045900, Rio de Janeiro, RJ, Brasil.

e-mail: alynnedsb@gmail.com 


\section{Introduction}

Balantidium coli is a ciliate protozoon that can parasitize the large intestine of a wide variety of animals. Domestic pigs and nonhuman primates are the animals that are generally most affected by this parasite. These animals are considered to be important sources of infection for humans (SCHUSTER \& RAMIREZ-AVILA, 2008). The parasite has two evolutionary stages: trophozoite and cyst. The trophozoites are of elongated or ovoid shape, with a length that can range from $30 \mu \mathrm{m}$ to $300 \mu \mathrm{m}$ and a width from $30 \mu \mathrm{m}$ to $100 \mu \mathrm{m}$. The cysts are spherical or ovoid, with diameters ranging from $40 \mu \mathrm{m}$ to $60 \mu \mathrm{m}$, and are generally thick-walled and hyaline (ZAMAN, 1978).

Transmission of this intestinal protozoon to humans and other animals occurs primarily through ingestion of cysts by means of direct contact between hosts. Indirect transmission occurs through ingestion of contaminated food and water. The clinical manifestations of balantidiasis can range from mild asymptomatic cases to severe cases of dysentery, which can progress to death (VÁSQUEZ \& VIDAL, 1999).

B. coli is considered to be a neglected pathogen, even though infections caused by this protozoon have now been reported in various parts of the world, including regions in the far north of the planet, such as Sweden, Finland, Norway and northern Russia. However, the highest prevalence rates are found in regions of tropical and subtropical climate, and the major endemic foci have been reported in Central and South America, especially in Brazil, Venezuela, Philippines, Papua New Guinea, parts of Asia and the Pacific Islands (SCHUSTER \& RAMIREZ-AVILA, 2008; SOLAYMANI-MOHAMMADI \& PETRI, 2006).

The diagnosis of balantidiasis is mainly based on detection of trophozoites and cysts in feces, by means of optical microscopy (SOLAYMANI-MOHAMMADI \& PETRI, 2006). In diarrheal samples, which predominantly contain trophozoites, direct examination is recommended, since the ciliary movement, protozoan macronucleus size and format are features that facilitate diagnosing the parasite (ANARGYROU et al., 2003).

The cystic form is usually found in solid and semi-solid stools (SCHUSTER \& RAMIREZ-AVILA, 2008). All the diagnostic studies that have been conducted have reported using different parasitological techniques. Castillo (2013) and Pereira (2010) reported using direct examination and spontaneous sedimentation, respectively, for diagnosing parasitic disease in human stool samples. In searching for protozoa in the feces of nonhuman primates, Lim et al. (2008) used sedimentation by means of centrifugation in ethyl acetate and Pourrut et al. (2011) direct examination together with centrifugal sedimentation in formalin-ether. In fecal samples from pigs, Guzman et al. (2013) opted for centrifugal flotation with zinc sulfate in association with direct examination, Nishi et al. (2000) used centrifugal flotation techniques with sucrose and centrifugal sedimentation with wather-ether and Weng et al. (2005) used direct examination and flotation with sodium chloride.

Despite reports of this disease in the literature, few studies have yet evaluated the effectiveness of diagnostic tests for detecting cystic forms of $B$. coli. Different laboratory procedures for detecting protozoa were only reported by Machado et al. (1969). Gold-standard techniques or diagnostic tests with $100 \%$ accuracy for estimating sensitivity and specificity are not generally available within parasitology, especially with regard to searching for intestinal parasites (GONÇALVES et al., 2014). Therefore, it is fundamentally important to review laboratory techniques in order to determine results of greater accuracy, which in turn will contribute greater amounts of information on the epidemiology of the parasite (TARAFDER et al., 2010; HARHAY et al., 2011).

The laboratory diagnostic techniques that are used to intestinal parasites have different fundamentals and processing, with advantages and limitations (DRYDEN et al., 2005). Currently, most of the methods used for detecting intestinal parasites involve use of solutions and reagents that minimize fecal debris and facilitate viewing of parasite structures. Furthermore, parasitology laboratories rely on using centrifuges and microscopes, which decrease the time required to carry out inspections and increase the accuracy of the results (PROUDMAN \& EDWARDS, 1992). However, these techniques have specific methods and comparison studies are needed in order to define which of these are more sensitive and faster.

Because of the low amount of information about B. coli in the literature, especially regarding diagnostic methodology, this study aimed to analyze detection of cysts of this parasite in stool samples from different hosts using five parasitological techniques, with comparison of cyst recovery efficiency between these techniques.

\section{Materials and Methods}

\section{Ethical considerations}

This study was approved by the Animal Ethics Committee (CEUA-Fiocruz), under license number LW57/12, protocol P79/11-2, and under SISBIO-IBAMA license, protocol number 31900-2.

\section{Sample collection}

Between August 2012 and January 2014, 1905 fecal samples were collected from captive animals in the state of Rio de Janeiro. Of these, 790 were obtained from pigs (Sus scrofa), as follows: 88 samples from animals on family farms located in the municipalities of Rio Bonito (21), Araruama (7), Saquarema (12), Maricá (8), Itaboraí (12) Casimiro de Abreu (23) and Silva Jardim (5) and 702 from industrial farming in Petrópolis (479) and Itaperuna (223). In relation to nonhuman primates, 960 samples were collected from the Fiocruz laboratory animal breeding center (CECAL), located in the city of Rio de Janeiro, and 155 from the Primate Center of the state of Rio de Janeiro (CPRJ; INEA), located in the municipality of Guapimirim.

More than 30 species of New World (NW) primates were represented in this study, particularly the genera Cebuella, Callithrix, Calibella, Mico, Saguinus, Leontopithecus, Callimico, Aotus, Callicebus, Saimiri, Cebus, Pithecia, Chiropotes, Cacajao, Alouatta, Ateles and Brachyteles, which are mainly found at the 
CPRJ, and two Old World (OW) species of the genera Macaca, which were kept at CECAL, Fiocruz.

Fecal samples from pigs were obtained directly from the rectum of each animal, using palpation gloves. For sampling purposes, in family farms, as many animal samples were collected as possible, since the number of pigs on each farm was small. In relation to industrial farms, a confidence interval of $80 \%$ was used, with $5 \%$ accuracy, with the exception of a farm in Petrópolis, where convenience sampling was used in some sectors, with at least 100 fecal samples collected, considering that there were more than 1,000 animals in enclosures.

In relation to nonhuman primates, it was decided to collect fecal samples from the floors of their enclosures, with the aim of minimizing the stress resulting from the animal containment process. The samples were standardized according to each site studied. At CECAL, there were a large number of animals with little variety of species and samples were collected in a timely manner (once in each enclosure), such that the number of samples was equal to the number of animals in each enclosure. On the other hand, at the CPRJ, a wide variety of primate species was presented, with fewer individuals than at CECAL. At this location, most of the macaques belonged to the genera Mico, Saguinus, Callithrix and Leontopithecus, and therefore were smaller primates that defecated small fecal volumes. To increase the volume of the sample and thus ensure that quality laboratory techniques were attained, the material collected was analyzed on three consecutive days, and these triple analyses were considered as a single sample.

In all collections, preference was given to fresh feces. These were deposited in plastic receptacles of volume $80 \mathrm{ml}$ without chemical preservative, and then packed in vacuum vessels. The fecal samples were sent to the Parasitology Laboratory of the Biomedical Institute, Federal Fluminense University.

\section{Processing of fecal samples}

Some of the material was immediately processed for direct examination with buffered saline. Another portion of the samples was homogenized and the resulting filtrate was place in $15 \mathrm{~mL}$ conical-bottom centrifuge tubes and was subjected to centrifugal sedimentation as described by Ritchie (1948) and modified by Young et al. (1979); centrifugal flotation as described by Faust et al. (1938), using zinc sulfate solution of density $1.180 \mathrm{~g} / \mathrm{cm}^{3}$; and centrifugal flotation as described by Sheather (1923) and modified by Huber et al. (2003), using a sucrose solution with a density of $1.300 \mathrm{~g} / \mathrm{cm}^{3}$. Part of the filtrate was subjected to the spontaneous sedimentation technique of Lutz (1919).

A single microscope slide was obtained from each parasitological technique. This was read using an Olympus ${ }^{\oplus}$ BX 41 optical microscope, initially at a magnification of $100 \times$, and then at a magnification of $400 \times$ for confirmation, if necessary.

\section{Statistical treatment}

The $\chi^{2}$ statistical test was used to compare the recovery of B. coli cysts from fecal samples from hosts achieved through using different parasitological techniques. Kappa statistics $(\mathrm{k})$ were used to determine the concordance between the parasitological diagnostic techniques. The SPSS software (SPSS Inc., 2009 release; PASW Statistics for Windows, version 18.0. Chicago: SPSS Inc., IBM, United States) was used, and the significance level was taken to be $5 \%$.

The kappa index was interpreted as follows: $<0$, poor agreement; $0-0.20$, slight agreement; 0.21 to 0.40 , fair agreement; $0.41-0.60$, moderate agreement; 0.61-0.80, substantial agreement; and 0.81-1.0, almost perfect agreement (LANDIS \& KOCH, 1977).

\section{Results}

Among the fecal samples from pigs and nonhuman primates that were studied, respectively $49.2 \%$ and $41.5 \%$ were positive for evolving forms of $B$. coli and $42.6 \%$ and $29.5 \%$ showed the cystic form, through associations of five parasitological techniques (Table 1). Of the $463 \mathrm{fecal}$ samples of nonhuman primates positive for trophozoites and cysts of B. coli, 11 (2.3\%) were obtained of nonhuman primates of the New World (NW), while 452 $(97.6 \%)$ were of nonhuman primates of the Old World (OW) Fecal material with cysts were detected in $9(1.9 \%)$ fecal samples of NW primates and $320(69.1 \%)$ in fecal samples from OW nonhuman primates (Data not shown in table).

B. coli cysts were diagnosed most frequently through direct examination (22.4\%), followed by the Lutz sedimentation technique (21\%) and modified Ritchie technique (20.5\%). The flotation technique of Faust and the modified Sheather technique showed poor performance in detecting cysts. In comparing the positive fecal samples from pigs and nonhuman primates, a statistically significant difference could only be observed through direct examination $(\mathrm{p}$ value $=0.00)$ and the Lutz technique $(\mathrm{p}$ value $=0.01)$ $(\mathrm{p}<0.05)$ (Table 2).

The highest values for the kappa index were observed in comparisons between direct examination and Lutz, between direct examination and modified Ritchie and between Lutz and modified Ritchie. Only the comparison between direct examination and Lutz presented a fair degree of agreement. Other comparisons were classified as slight or poor. All the kappa values were statistically significant, with $\mathrm{p}<0.05$ (Table 3).

\section{Discussion}

In this study, the associations between the five parasitological techniques made it possible to diagnose $B$. coli cysts, in the feces samples both from pigs and from nonhuman primates. It is known that simultaneous use of different techniques with different fundamentals increases the accuracy in diagnosing parasitic diseases

Table 1. Frequency of evolutionary forms of Balantidium coli detected in fecal samples from pigs and non-human primates.

\begin{tabular}{lccc}
\hline \multicolumn{1}{c}{ No of samples } & $\begin{array}{c}\text { Pigs } \\
(\mathbf{N}=\mathbf{7 9 0})\end{array}$ & $\begin{array}{c}\text { Primates } \\
(\mathbf{N}=1115)\end{array}$ & Total (1905) \\
\hline $\begin{array}{l}\text { Positivity total } \\
\text { (trophozoites and cysts) }\end{array}$ & $389(49.2 \%)$ & $463(41.5 \%)$ & $852(44.7 \%)$ \\
Positive for cysts & $337(42.6 \%)$ & $329(29.5 \%)$ & $666(34.9 \%)$ \\
\hline
\end{tabular}


Table 2. Detection of cysts of Balantidium coli in stool samples from pigs and nonhuman primates detected through the direct examination, Lutz, modified Ritchie, Faust et al. and modified Sheather techniques.

\begin{tabular}{|c|c|c|c|c|}
\hline \multirow{2}{*}{ Techniques } & $\begin{array}{c}\text { Total } \\
(\mathrm{N}=1905)\end{array}$ & $\begin{array}{c}\text { Pigs } \\
(\mathrm{N}=790)\end{array}$ & $\begin{array}{c}\text { Primates } \\
(\mathrm{N}=1115)\end{array}$ & $p$ value \\
\hline & No+ & No+ & No+ & $\begin{array}{c}\text { (Pig X } \\
\text { Primate) }\end{array}$ \\
\hline ED & $427(22.4 \%)$ & $211(26.7 \%)$ & $216(19.3 \%)$ & $0.00^{*}$ \\
\hline Lutz & $401(21 \%)$ & $146(18.4 \%)$ & 255 (22.8\%) & $0.01^{*}$ \\
\hline Ritchie mod. & $391(20.5 \%)$ & $158(20 \%)$ & $233(20.8 \%)$ & 0.33 \\
\hline Faust & $74(3.8 \%)$ & $41(5.1 \%)$ & $33(2.9 \%)$ & 0.07 \\
\hline $\begin{array}{l}\text { Sheather } \\
\text { mod. }\end{array}$ & $21(1.1 \%)$ & $6(0.7 \%)$ & $15(1.3 \%)$ & 0.16 \\
\hline
\end{tabular}

No+: number of positive samples. ED: Direct Examination. ${ }^{*} \mathrm{p}<0.05$.

Table 3. Concordance of the results obtained through parasitological techniques applied to Balantidium coli cysts that were detected in stool samples from pigs and nonhuman primates.

\begin{tabular}{|c|c|c|c|}
\hline Techniques & $\begin{array}{l}\text { Total } \\
\text { No+ }\end{array}$ & $\mathbf{k}$ & p value \\
\hline ED X Lutz & 227 & 0.41 & 0.02 \\
\hline ED X Ritchie mod. & 208 & 0.37 & 0.02 \\
\hline ED X Faust et al. & 40 & 0.10 & 0.02 \\
\hline ED X Sheather mod. & 9 & 0.20 & 0.01 \\
\hline Lutz X Ritchie mod. & 188 & 0.34 & 0.02 \\
\hline Lutz X Faust et al. & 41 & 0.11 & 0.02 \\
\hline Lutz X Sheather mod. & 14 & 0.04 & 0.01 \\
\hline Ritchie mod. X Faust & 47 & 0.14 & 0.02 \\
\hline Ritchie mod. X Sheather mod. & 17 & 0.06 & 0.01 \\
\hline Faust et al. X Sheather mod. & 11 & 0.22 & 0.05 \\
\hline
\end{tabular}

No+: number of positive samples. ED: Direct Examination. $k=$ Kappa. $p \leq 0.05$. Kappa $<0$, poor agreement; $0-0.20$, slight agreement; 0.21 to 0.40 , fair agreement; 0.41-0.60, moderate agreement; $0.61-0.80$, substantial agreement; and 0.81-1.0, almost perfect agreement.

(CARVALHO et al., 2002). Most research studies on detection of $B$. coli have reported using one parasitological technique (CASTILLO, 2013; PEREIRA, 2010) or at most two techniques (GUZMÁN et al., 2013; NISHI et al., 2000; POURRUT et al., 2011; WENG et al., 2005). In some studies, associations between permanent staining methods were used (LIM et al., 2008). In the present study, in order to detect $B$. coli, fresh fecal samples were always collected and used without preservatives in five methods: direct examination, two sedimentation techniques (Lutz and modified Ritchie) and two flotation techniques (Faust et al. and modified Sheather). Similarly, Machado et al. (1969) chose to use parasitological procedures with different fundamentals, such direct examination, a sedimentation technique (Lutz) and two flotation methods (Faust et al. and Willis), in order to investigate B. coli in human fecal samples in the city of Niterói, Brazil.

Overall, direct examination was the test that showed the greatest recovery of $B$. coli cysts (22.4\%). At the time of implementing this test, the fecal material was subjected to withdrawal of aliquots from various points, both at the surface and at some depth. It is believed that $B$. coli cysts tend to be concentrated more on the superficial layer of the fecal cake, because in the large intestine, the material from the digested food goes through a few homogenization movements, thus hindering the spread of parasitic structures. Stool surface scrapings may have favored the frequency of detection of cysts through direct examination (Figure 1A). This higher concentration of parasite structures on the surface of the stool has already been proven positive in fecal samples, in relation to eggs of Schistosoma sp. (Trematoda), which are released in the large intestine wall (YE et al., 1998).

Comparing the efficiency of fecal parasitological techniques for different hosts, a statistically significant difference in the frequency of $B$. coli cysts can be seen between direct examination and Lutz. Prolonged adaptation of pigs to $B$. coli parasites may have contributed towards making this animal an excellent reservoir. It is a host with high production of cystic forms, which in this study were detected mainly through direct examination. According to Estevez \& Levine (1985), direct examination has many advantages, especially its methodological simplicity and short runtime, and it is recommended for trophozoite detection in stools without chemical preservative. They noted that direct examination is currently the routine parasitological diagnostic laboratory technique for stools that has the lowest cost.

Cyst recovery capability with a somewhat lower positivity rate was observed in the Lutz sedimentation technique and modified Ritchie method: $21 \%$ and 20.5\%, respectively (Figure 1B, C). On fecal samples from nonhuman primates, the Lutz technique showed a mean rate of $22.8 \%$, which explains the significant difference in comparing the efficiency of technology between samples from different hosts. Studies on fecal samples from non-human primates have shown lower fecal volumes than samples from pigs. These lower volumes may have promoted concentration of parasite structures, which should have favored greater recovery of parasites through sedimentation techniques. It is noteworthy that the primates nonhuman of the OW were those with higher rates of evolutionary forms of $B$. coli, and so was the group of primates that most contributed to the analyzes of the techniques.

Although B. coli is an intestinal protozoon, its cysts present dimensions compatible with some helminth eggs. This size, together with high density, favors their detection by means of the Lutz and modified Ritchie techniques, which are primarily indicated for diagnosing heavy parasitic structures, such as the eggs and larvae of helminths (Dryden et al., 2005; Taparo et al., 2006). According to Truant et al. (1981), spontaneous sedimentation has the advantage of enabling recovery of the developmental forms of parasites without deforming them and thus maintaining the viability of the parasite structure. However, a long running period may be needed, depending on the settling time applied, which may vary from 1 to 24 hours.

The Ritchie technique used in this study was used as modified by Young et al. and proposed by Cerqueira (1988). Young et al. (1979) replaced ether with ethyl acetate, because of its toxic effect. According to these authors, this change increased the efficiency of detection of progression patterns, especially for Giardia duodenalis cysts and Hymenolepis nana eggs. Furthermore, ethyl acetate is less flammable than ether, and thus there are no limitations to its use. Years later, Cerqueira added neutral detergent to this technique: 

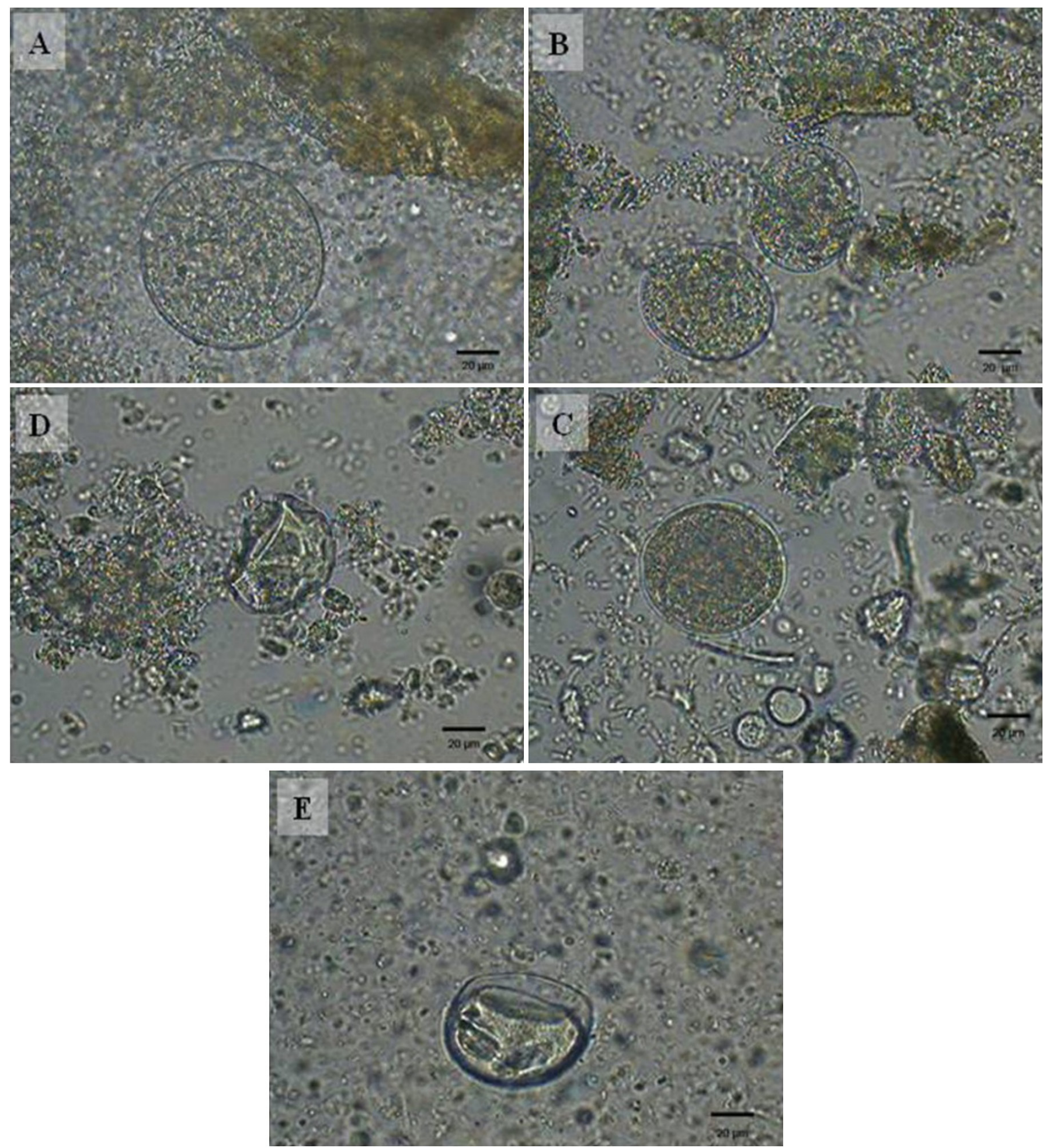

Figure 1. Cysts of Balantidium coli detected in stool samples from pigs and nonhuman primates through different parasitological techniques: (A) - direct examination; (B) - Lutz (1919); (C) - Ritchie, as modified by Young et al. (1979); (D) - Faust et al. (1938); (E) - Sheather, as modified by Huber et al. (2003) scale bar: $20 \mu \mathrm{m}$.

when this is combined with ethyl acetate, removal of fat and fibrous fecal material is favored.

The microscope slides resulting from direct examination and from the Lutz and modified Ritchie sedimentation techniques generally have much waste, thus making it difficult to view structures. To minimize this limitation, it was decided in this study to use cover slips measuring $24 \times 32 \mathrm{~mm}$, i.e. larger than those used in routine laboratory analyses $(22 \times 22 \mathrm{~mm})$. The greater size of the cover slips made it possible to spread the fecal material, thus facilitating reading of the sediment. 
The Faust and modified Sheather techniques showed low recovery of $B$. coli cysts from fecal samples of both pigs and nonhuman primates. These results are contrary to those of Machado et al. (1969) who reported that the Faust technique showed the highest diagnostic efficiency for $B$. coli cysts $(0.74 \%)$, followed by direct examination $(0.57 \%)$, spontaneous sedimentation $(0.49 \%)$ and Willis (0.49\%), in 1214 human stool samples. They noted that flotation techniques are used primarily to recover cysts and oocysts of protozoa, through processing with solutions of different densities, which facilitates floatation of light parasite structures (DRYDEN et al., 2005). High sensitivity of cyst and oocyst recovery has been demonstrated by several authors. Machado et al. (2001) reported that the technique of Faust showed higher positivity of $G$. duodenalis in the feces of children than did iron hematoxylin, direct examination using Lugol's solution or enzyme immunoassay. Likewise, Huber et al. (2003) showed higher frequency of Cryptosporidium spp. oocysts and $G$. duodenalis cysts in the feces of calves by using the modified Sheather technique than by using sedimentation with formaldehyde-ether.

The modified Sheather technique used by Huber et al. (2003) was the same as applied in the present study, using a high-density sucrose solution $\left(1.30 \mathrm{c} / \mathrm{cm}^{3}\right)$. According to Broussard (2003), the Sheather technique is the one that has been most widely used in veterinary parasitology and the technique of Faust can already be considered to be the gold standard technique for Giardia spp. However, in the present study, the Faust and modified Sheather techniques showed low efficiency in making the diagnosis, given that these techniques also gave rise to morphological changes to the cysts, which often made it difficult to recognize them (Figure 1D, E).

In all the comparisons, the kappa index was statistically significant thus showing that the results were reliable. The highest kappa values were observed between direct examination and Lutz, i.e. the techniques that showed the highest frequency of positivity. While this agreement was classified as fair, it was still far from the maximum (kappa value $=1$ ). Therefore, to increase the efficiency of diagnosing $B$. coli cysts, the results indicate that there is a need to combine direct examination with a sedimentation technique.

In making parasitological diagnoses, laboratory methodologies should always be previously evaluated according to the parasite species. As can be seen from the present study, the centrifugal flotation techniques did not present good recovery rates for $B$. coli cysts and therefore are not suitable for investigating this protozoon. However, it should be emphasized that performing direct examination made it possible not only to investigate trophozoites in B. coli, but also to diagnose the cysts. The association between direct examination and Lutz was the best method for diagnosing this parasitosis.

\section{Acknowledgements}

The authors would like to thank the following for project support: FAPERJ (Research Support Foundation of the State of Rio de Janeiro, grant number E26/110 440/2012), IOC (Oswaldo Cruz Institute), PROPPI-UFF (Dean's Office for Research and Innovation Studies of the Federal Fluminense University) and
PROAES-UFF (Dean's Office for Student Affairs of the Federal Fluminense University).

\section{References}

Anargyrou K, Petrikkos GL, Suller MTE, Skiada A, Siakantaris MP, Osuntoyinbo RT, et al. Pulmonary Balantidium coli infection in leukemic patient. Am J Hematol 2003; 73(3): 180-183. http://dx.doi.org/10.1002/ ajh.10336. PMid:12827655.

Broussard JD. Optimal fecal assessment. Clin Tech Small Anim Pract 2003; 18(4): 218-230. http://dx.doi.org/10.1016/S1096-2867(03)00076-8. PMid:14738202.

Carvalho FM, Falcáo AO, Albuquerque MC, Silva P, Bastos OMP, Uchôa CMA. Diagnóstico coproparasitológico: estudo comparativo entre os métodos de Faust e Cols., Lutz, Baermann e Moraes e Coprotest. Rev Bras Anal Clin 2002; 34(2): 75-77.

Castillo KES. Identificación de Balantidium coli en personas dedicadas a la porcicultura en el cantón balsas durante septiembre 2012 a febrero 2013 [Monografia]. Equador: Universidad Nacional de Loja; 2013.

Cerqueira FL. Coprotest: reliable methodology for stool testing. Laes 1988; 51: 5-12.

Dryden MW, Payne PA, Ridley R, Smith V. Comparison of common fecal flotation techniques for the recovery of parasite eggs and oocysts. Vet Ther 2005; 6(1): 15-28. PMid:15906267.

Estevez GE, Levine JA. Examination of preserved stool specimens for parasites: lack of value of the direct wet mount. J Clin Microbiol 1985; 22(4): 666-667. PMid:2416772.

Faust EC, D’Antoni JS, Odon V, Miller MJ, Perez C, Sawitz W, et al. A critical study of clinical laboratory technics for the diagnosis of protozoan cysts and helminth eggs in feces. I. Preliminary communication. Am J Trop Med Hyg 1938; 18(2): 169-183.

Gonçalves AQ, Abellana R, Silva HDP, Santos I, Serra PT, Julião GR, et al. Comparison of the performance of two spontaneous sedimentation techniques for the diagnosis of human intestinal parasites in the absence of a gold standard. Acta Trop 2014; 131: 63-70. http://dx.doi.org/10.1016/j. actatropica.2013.11.026. PMid:24321383.

Guzmán CR, Nessi AP, Gonzáles OH, Hernández MO, Galindo M. Balantidium spp. en cerdos y sus criadores: Prevalencia em comunidades de dos Estados de Venezuela. VITAE 2013; 54: 1-10.

Harhay MO, Horton J, Olliaro PL, Utzinger J. Diagnostics are central for a truly holistic approach against intestinal parasitic diseases. Int J Infect Dis 2011; 15(2): 76-77. http://dx.doi.org/10.1016/j.ijid.2010.10.007. PMid:21145770.

Huber F, Bomfim TC, Gomes RS. Comparação da eficiência da técnica de sedimentação pelo formaldeído-éter e da técnica de centrífugoflutuação modificada na detecção de cistos de Giardia sp. e oocistos de Cryptosporidium sp. em amostras fecais de bezerros. Rev Bras Parasitol Vet 2003; 12(2): 135-137.

Landis JR, Koch GG. The measurement of observer agreement for categorical data. Biometrics 1977; 33(1): 159-174. http://dx.doi. org/10.2307/2529310. PMid:843571.

Lim YAL, Ngui R, Shukri J, Rohela M, Mat Naim HR. Intestinal parasites in various animals at a zoo in Malaysia. Vet Parasitol 2008; 157(1-2): 154159. http://dx.doi.org/10.1016/j.vetpar.2008.07.015. PMid:18723289. 
Lutz AOO. Schistosomum mansoni e a Schistosomatose segundo observações, feitas no Brazil. Mem Inst Oswaldo Cruz 1919; 11(1): 121-155. http:// dx.doi.org/10.1590/S0074-02761919000100006.

Machado O, Pinho AL, Silva S. Aspectos parasitológicos na balantidíase humana. O Hospital 1969; 75: 1969-1976.

Machado RLD, Figueredo MC, Frade AM, Kudó ME, Silva MGS Fo, Póvoa MM. Comparação de quatro métodos laboratoriais para diagnóstico da Giardia lamblia em fezes de crianças residentes em Belém, Pará. Rev Soc Bras Med Trop 2001; 34(1): 91-93. http://dx.doi.org/10.1590/S003786822001000100014. PMid:11340503.

Nishi SM, Gennari SM, Lisboa MNTS, Silvestrim A, Caproni L Jr, Umehara O. Parasitas intestinais em suínos confinados nos Estados de São Paulo e Minas Gerais. Arq Inst Biol (Sao Paulo) 2000; 67(2): 199-203.

Pereira C. Occurence of shistosomiasis and the others intestinal parasites in children and teenager of a public school in Jequié, Bahia, Brazil. Rev Saúde.com 2010; 6(1): 24-30.

Pourrut X, Diffo JLD, Somo RM, Bilong Bilong CF, Delaporte E, Lebreton $\mathrm{M}$, et al. Prevalence of gastrointestinal parasites in primate bushmeat and pets in Cameroon. Vet Parasitol 2011; 175(1-2): 187-191. http://dx.doi. org/10.1016/j.vetpar.2010.09.023. PMid:20970258.

Proudman CJ, Edwards GB. Validation of a centrifugation/flotation technique for the diagnosis of equine cestodiasis. Vet Rec 1992; 131(4): 71-72. http://dx.doi.org/10.1136/vr.131.4.71. PMid:1529504.

Ritchie LS. An ether sedimentation technique for routine stool examinations. Bull US Army Med Dep 1948; 8(4): 326. PMid:18911509.

Schuster FL, Ramirez-Ávila L. Current world status of Balantidium coli. Clin Microbiol Rev 2008; 21(4): 626-638. http://dx.doi.org/10.1128/ CMR.00021-08. PMid:18854484.

Sheather AT. The detection of intestinal protozoa and monge parasites by a flotation technique. J Comp Pathol 1923; 36: 266-275. http://dx.doi. org/10.1016/S0368-1742(23)80052-2.
Solaymani-Mohammadi S, Petri WA Jr. Zoonotic implications of the swine-transmitted protozoal infections. Vet Parasitol 2006; 140(3-4): 189203. http://dx.doi.org/10.1016/j.vetpar.2006.05.012. PMid:16828229.

Táparo CV, Perri SHV, Serrano ACM, Ishizaki MN, Costa TP, Amarante AFT, et al. Comparação entre técnicas coproparasitológicas no diagnóstico de ovos de helmintos e oocistos de protozoários em cáes. Rev Bras Parasitol Vet 2006; 15(1): 1-5. PMid:16646994.

Tarafder MR, Carabin H, Joseph L, Balolong E Jr, Olveda R, McGarvey ST. Estimating the sensitivity and specificity of Kato-Katz stool examination technique for detection of hookworms, Ascaris lumbricoides and Trichuris trichiura infections in humans in the absence of a 'gold standard'. Int J Parasitol 2010; 40(4): 399-404. http://dx.doi.org/10.1016/j. ijpara.2009.09.003. PMid:19772859.

Truant AL, Elliott SH, Kelly MT, Smith JH. Comparison of formalinethyl ether sedimentation, formalin-ethyl acetate sedimentation, and zinc sulfate flotation techniques for detection of intestinal parasites. $J$ Clin Microbiol 1981; 13(5): 882-884. PMid:7240400.

Vásquez W, Vidal J. Colitis balantidiásica: a propósito de un caso fatal en el departamento de Huancavelica. Anales Facul Med Sao Marcos 1999 60(2): 119-123.

Weng YB, Hu YJ, Li Y, Li BS, Lin RQ, Xie DH, et al. Survey of intestinal parasites in pigs from intensive farms in Guangdong Province, People's Republic of China. Vet Parasitol 2005; 127(3-4): 333-336. http://dx.doi. org/10.1016/j.vetpar.2004.09.030. PMid:15710534.

Ye XP, Donnelly CA, Anderson RM, Fu YL, Agnew A. The distribution of Schistosoma japonicum eggs in feces and the effect of stirring fecal specimens. Ann Trop Med Parasitol 1998; 92(2): 181-185. http://dx.doi. org/10.1080/00034989860021. PMid:9625914.

Young KH, Bullock SL, Melvin DM, Spruill CL. Ethyl acetate as a substitute for diethyl ether in the formalin-ether sedimentation technique. J Clin Microbiol 1979; 10(6): 852-853. PMid:574877.

Zaman V. Balantidium coli. In: Kreier JP, editor. Parasitic protozoa. New York: Academic Press; 1978. p. 633-653. 